\title{
Pengaruh Penggunaan Alat Peraga dari Bahan Bekas tentang Sistem Peredaran Darah pada Manusia Terhadap Hasil Belajar Biologi Siswa Kelas XI SMA Negeri 7 Kota Kupang Tahun Ajaran 2014/2015
}

\section{The Effect of the Use of Props from Scrap Materials on the Human Blood Circulatory System to the Learning Outcomes Biology of the Students XI SMAN 7 Kupang in the Academic Year 2014/2015}

\author{
FRANSINA TH. NOMLENI, JAMES E. MERUKH \\ Universitas Kristen Artha Wacana Kupang \\ Jl. Adi Sucipto, Oesapa' PO.BOX 147, Kupang, Indonesia \\ *email: nomlenifince@gmail.com
}

Manuscript received: 5 Mei 2014 Revision accepted: 17 Juli 2014

\begin{abstract}
This study aims to determine the effect ofthe use of props from scrap material son the human circulatory system to the learning outcomes compared to the results of studying biology classes which were not taught using the media props in class XI SMAN 7 Kupang in the academic year 2014/2015. Problems encountered in the scholar teachers do not use visual media in learning process so the impact is on learning outcomes biology students who do not achieve KKM 70. The method used in this study is the experimental method by using quasi-experimental design. Data collection was performed by using the test results of pretest and posttest as well as documentation. Results of pretest and post test data were analyze dusing $t$ test formula with two groups design. The results showed that there were differences in learning outcomes between classes that were taught by using media props circulatory system of scrap materials that the average value of the pretest value $X=39.03$ while the posttest value $X=80.80$ and classes that were taught by not using media props circulatory system of scrap materials pretest value $Y=37.58$ and posttest value $Y=65.48$. The difference between the two classes of learning outcomes is also indicated by the results of the calculations to test the hypothes is using the ttest the $t$ value is 5.74, while $t$ table is 2.000 . Can be concluded that there is the effect of using props froms crap materials on the human circulatory system of the human circulatory systemina better effect on learning outcomes compared to biology student learning outcomes and students who were taught not use theme diapropsin class XI SMAN 7 Kupang in the academic year 2014/2015. So it is recommended to teachers and prospective teachers in order to teach the material of the human circulatory system can use visual aids blood circulation system of scrap materials and also both teachers and prospective teachers can make props of scrap materials in other subject matter.
\end{abstract}

Keywords: Human visual aidsbloodcirculatorysystem, learning outcomes

\section{LATAR BELAKANG}

Guru adalah salah satu komponen pendidikan tentunya mempunyai peran yang penting dalam upaya pencapaian tujuan pendidikan. Dalam proses belajar guru mempunyai tugas untuk memilih model pembelajaran berikut media yang tepat sesuai dengan materi yang disampaikan demi tercapainya tujuan pembelajaran. Guru sebagai fasilitator dapat memfasilitasi siswa dengan sarana dan prasarana yang dapat mendukung dalam proses pembelajaran supaya hasil belajar siswa dalam proses pembelajaran sesuai dengan yang diinginkan.

Hasil wawancara mengenai peran guru sebagai fasilitator di lokasi penelitian dalam hal ini dapat menfasilitasi siswa dengan sarana dan prasarana yang mendukung proses belajar-mengajar kepada siswa, untuk materi peredaran darah pada manusia belum menggunakkan media dalam pembelajarannya. Karena tidak menggunakan media akibatnya dalam kegiatan belajar mengajar (KBM) hanya terjadi komunikasi verbal saja sehingga membuat kondisi siswa di kelas pasif, siswa tidak memperhatikan saat guru megajar di depan kelasdan tentunya hal ini berdampak pada nilai hasil belajar biologi siswa yang rendah. Menurut (Komalasari 2010: 111) cara belajar dengan mendengarkan ceramah dari guru merupakan wujud salah satu interaksi. Namun, belajar dengan hanya mendengarkan saja patut diragukan efektifitasnya. Belajar hanya akan efektif jika siswa diberikan banyak kesempatan untuk melakukan sesuatu melalui multimetode dan multimedia.

Informasi yang diperoleh melalui observasi dan wawancara dari guru mata pelajaran biologi SMA Negeri 7 Kota Kupang semakin menguatkan bahwa dampak dari pembelajaran yang tidak menggunakan media dalam pembelajarannya berdampak kepada hasil belajar siswa. Hal di atas terlihat dari hasil ulangan harian siswa yaitu ulangan hariannya belum mencapai Kriteria Ketuntasan 
Minimal (KKM) 70, kelas XI IPA 3 jumlah siswa 30 orang, dengan nilai rata-rata ulangan hariannya mencapai ataupun lebih dari KKM sebanyak 12 siswa artinya yang tuntas $38 \%$ sedangkan yang tidak tuntas $68 \%$ atau ratarata nilainya 59,30 dan kelas XI IPA 4 jumlah siswa 31 orang, dengan nilai rata-rata ulangan harian yang mencapai KKM sebanyak 15 orang artinya yang tuntas $48 \%$ sedangkan yang tidak tuntas $52 \%$ atau nilai rataratanya 61,83 .

\section{METODE}

Metode yang digunakan dalam penelitian ini adalah metode eksperimen, dengan desain kuasi eksperimen.

\section{Prosedur Penelitian}

\section{Tahap Perencanaan}

a. Mengurus dan mempersiapkan surat izin penelitian

b. Peneliti menyiapkan rencana pelaksaan pembelajaran (RPP)

c. Mempersiapkan soal tes disertai kunci jawabannya

d. Peneliti menyiapkan alat peraga yang akan digunakan dalam pembelajaran.

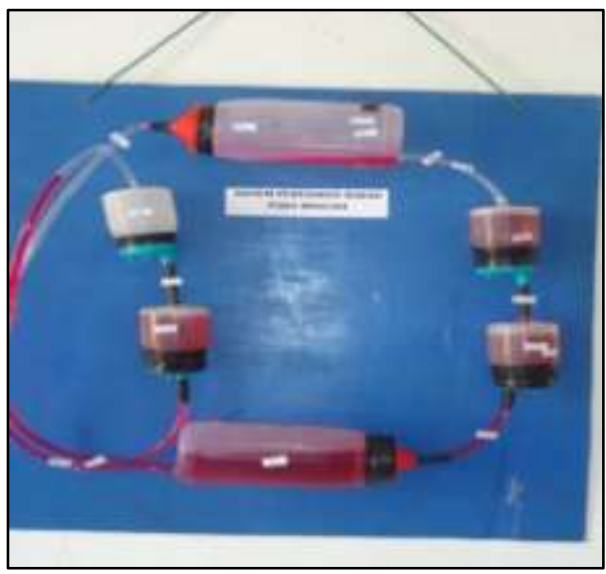

Gambar 2. Desain Model Sistem Peredaran Darah

\section{Cara Membuat Alat Peraga}

Bahan dan Alat:

a. 6 buah botol plastik transparan;

b. Selang kecil diameter $3,5 \mathrm{~cm}$;

c. 2 buah gotri kecil;

d. 2 buar per kecil dari gel pen

e. Air dan tinta print merah sebagai pewarna darah

\section{Bagian-bagian alat peraga}

a. Alat peraga ini membutuhkan 6 buah botol (2 botol untuk serambi kiri dan kanan dan 2 botol untuk bilik kiri dan bilik kanan, 1 botol untuk seluruh tubuh dan 1 botol lagi sebagai paru-paru.

b. Selang transparan secukupnya dijadikan sebagai pembuluh darah

c. Katub jantung dibutuhkan selang, 2 buah gotri, 2 buah per dari pulpen yang bisa bergerak membuka dan menutup. d. Dilubangi bagian tutup dan dasar botol sebesar ukuran selang lalu rangkaikan botol dan selang seperti contoh gambar alat peraga sistem peredaran darah pada manusia.

e. Rangkaian alat peraga ditempelkan pada triplek

f. Rangkaian botol yang telah jadi, diisi dengan air dan pewarna makanan berwarna merah sebagai darah.

\section{Cara Menggunakan alat peraga sistemperedaran darah dalam pembelajaran.}

a. Ketika bilik kiri jantung buatan ditekan air akan mengalir dari bilik kiri menuju keseluruh tubuh melalui pembuluh nadi, kemudian menuju ke serambi kanan melalui pembuluh balik. Air tidak bisa masuk ke serambi kiri karena katub jantung kiri menutup dan katup kanan akan terbuka ketika bilik kiri ditekan

b. Begitu juga ketika bilik kanan ditekan air akan mengalir dari bilik kanan menuju ke paru-paru melalui pembuluh nadi paru-paru kemudian menuju ke serambi kiri melalui pembuluh balik katub akan terbuka ketika bilik paru-paru. Air tidak masuk ke serambi kanan karena katub jantung kanan akan menutup dan katup akan terbuka ketika bilik kanan ditekan.

c. Begitu seterusnya cara kerja alat. Gambaran fungsi jantung terhadap sirkulasi darah dilihat secara transparan karena semua bahan dibuat dari bahan yang transparan.

\section{Tahap pelaksanaan}

a. Guru mengkondisikan siswa dengan mencatat kehadiran siswa, mengarahkan siswa untuk menyiapkan buku-buku yang berkaitan dengan mata pelajaran biologi;

b. Guru memberi acuan kepada siswa dengan menginformasikan tujuan pembelajaran yang akan dilaksanakan;

c. Guru melakukan pretes pada siswa untuk mengetahui kemampuan awal siswa pada kelas eksperimen maupun kelas kontrol;

d. Guru mendemonstrasikan dan menjelaskan materi sistem peredaran darah pada manusiadengan menggunakan alat peraga pada kelas eksperimen, sedangkan pada kelas kontrol tidak menggunakan alat peraga.

Tahap akhir

Guru mengadakan postes untuk megetahui hasil belajar kelas eksperimen dan kelas kontrol.

\section{TEKNIK PENGUMPULAN DATA}

Adapun teknik pengumpulan data dilakukan melalui tahapan yaitu: Observasi, Dokumentasi dan Tes hasil belajar yakni melakukan tes awal (pree test) dan tes akhir (post test)

\section{TEKNIK ANALISIS DATA}

Untuk menguji hipotesis penelitian dengan menggunakan rumus uji tPretest dan Postest two Group Design (Arikunto, 2006) adalah:

$$
t=\frac{M_{x}-M_{y}}{\sqrt{\left(\frac{\sum x 2+\sum y^{2}}{N_{x}+N_{y}-2}\right)\left(\frac{1}{N_{x}}+\frac{1}{N_{y}}\right)}}
$$


Keterangan:

$\begin{array}{ll}\mathrm{t} & =\text { Koefisien derajat perbedaan mean kedua } \\ \text { kelompok } & \\ \mathrm{Mx} & =\text { Mean kelompok eksperimen } \\ \mathrm{My} & =\text { Mean kelompok kontrol } \\ \mathrm{X} & =\text { Deviasi setiap } \mathrm{x}_{2} \text { dan } \mathrm{x}_{1} \\ \mathrm{Y} & =\text { Deviasi setiap } \mathrm{y}_{2} \text { dan } \mathrm{y}_{1} \\ \mathrm{~N}_{\mathrm{x}} & \text { = Jumlah siswa kelompok eksperimen } \\ \mathrm{N}_{\mathrm{y}} & \text { = Jumlah siswa kelompok control }\end{array}$

\section{HASIL DAN PEMBAHASAN}

Di lihat dari nilai rata-rata hasil belajar siswa yang dalam pembelajarannya menggunakan alat peraga sistem peredaran darah dari bahan bekas nilai rata-rata hasil belajar pada pretes sama tetapi ketika diberi perlakuan yang berbeda terjadi perbedaan nilai rata-rata yang signifikan antara kelas yang pembelajarannya tidak menggunakan media alat peraga dan kelas yang dalam pembelajarannya menggunakan alat peraga. Pada kelas yang pembelajarannya tidak menggunakan media alat peraga (kelas kontrol MIA 4) jumlah siswa yang mencapai KKM $\geq 70$ berjumlah 11 orang siswa atau $33 \%$, sedangkan yang tidak mencapai KKM berjumlah 20 orang siswa atau $67 \%$. Pada kelas yang diajarkan dengan bantuan alat peraga tentang sistem peredaran darah (kelas eksperimen XI MIA 3) jumlah siswa yang mencapai $K K M \geq 70$ mencapai 31 orang siswa atau $100 \%$. Dengan demikiana disimpulkan bahwa: $\mathrm{H}_{\mathrm{O}}$ diterima jika $\mathrm{t}_{\text {hitung }}<$ dari $\mathrm{t}_{\text {table }}$ atau sebaliknya $\mathrm{H}_{\mathrm{O}}$ ditolak dan $\mathrm{H}_{1}$ diterima jika $t_{\text {hitung }}>$ dari $t_{\text {tabel. }}$. Derajat bebas $(\mathrm{db})=\left(\mathrm{N}_{1}+\mathrm{N}_{2}-2\right)$ yaitu $(31+31-2)=60$. Dengan taraf signifikan $5 \%$ atau 0,05 adalah 2,000

Pada materi sistem peredaran darah pada manusia penggunaan alat peraga dalam pembelajaran menunjukkan hasil belajar siswa yang lebih baik daripada kelas yang diajarkan dengan tidak menggunakan media alat peraga selain itu, hal ini bisa terlihat dari antusias siswa ketika mengikuti pelajaran antara siswa yang diajar dengan alat peraga sangat antusias sampai akhir jam pelajaran, sedangkan pada kelas yang tidak menggunakan media alat peraga saja terlihat bahwa siswa cepat bosan. Pemilihan media yang tepat berpengaruh terhadap perhatian siswa di dalam kelas dan berlanjut pada meningkatnya hasil belajar siswa.

Hal ini sesuai dengan beberapa faktor yang mempengaruhi hasil belajar yaitu berkaitan dengan Pengajar yang professional yang dapat memilih media yang sesuai untuk pembelajaran, menciptakan atmosfir pebelajaran yang partisipatif dan interaktif di dalam kelas, dan sarana dan prasarana yang ada ataupun diciptakan untuk menunjang proses pembelajaran sehingga peserta didik merasa betah dan bergairah untuk belajar.

Penggunaan media alat peraga dalam pembelajaran dapat meletakkan dasar-dasar yang konkret untuk berpikir sehingga mengurangi verbalisme, memperbesar perhatian dan minat siswa terhadap materi pembelajaran, membuat pelajaran lebih menetap dengan tidak mudah dilupakan, memberi pengalaman yang nyata kepada siswa, membantu tumbuhnya perkembangan pikiran dan perkembangan bahasa, menarik siswa untuk membicarakan lebih lanjut sehingga hasil belajar siswa dapat meningkat.

Hal di atas didukung oleh pendapat Wina putra (2005:55) bahwa rata-rata informasi yang seseorang peroleh melalui indera adalah $75 \%$ melalui penglihatan (visual), 13\% melalui pendengaran (audio), 6\% melalui sentuhan, dan $6 \%$ melalui penciuman dan pengecapan. Sedangkan hasil belajar yang rendah akibat tidak menggunakan media dalam pembelajaran di kelas kontrol dapat menyebabkan terjadi verbalisme, karena tidak menggunakan media maka guru akan lebih banyak menjelaskan materi hal ini hanya memenuhi kebutuhan siswa dengan gaya belajar auditori (mendengarkan) sedangkan siswa dengan gaya belajar visual tidak terpenuhi kebutuhan belajarnya, dan bila pembelajaran yang diterapkan tidak menggunakan media dan hanya mendengarkan guru menjelaskan materi secara terusmenerus dapat menyebabkan siswa menjadi cepat bosan, dan ada kecenderungan membuat siswa di dalam kelas menjadi pasif.

Penggunaan alat peraga ini dapat memenuhi semua gaya belajar siswa berdasarkan modalitas. Alat peraga yang diperagakan guru memenuhi kebutuhan siswa dengan gaya belajar visual, penjelasan dari guru untuk melengkapi keterbatasan yang tidak dapat dijelaskan oleh alat peraga sehingga informasi yang diperoleh siswa lebih utuh hal ini memenuhi kebutuhan siswa denga gaya belajar auditori sedangkan kesempatan kepada siswa untuk mendemonstrasikan sendiri dapat memenuhi gaya belajar siswa yang Kinestetik hal ini dapat membuat pembelajaran yang disampaikan berkesan, mudah diingat dan berdampak untuk meningkatkan hasil belajar siswa.

\section{KESIMPULAN}

Berdasarkan hasil penelitian dan pembahasan penelitian dapat disimpulkan bahwa Penggunaan media alat peraga dalam pembelajaran menunjukkan pengaruh yang lebih baik terhadap hasil belajar siswa dibandingkan dengan hasil belajar siswa pembelajarannya tidak menggunakan media alat peraga dengan nilai $t_{\text {hitung }}>t_{\text {tabel }}$ yaitu $5,74>2,000$. Hal ini juga, terlihat dari perbedaan nilai ratarata kedua kelas Pretes $X=39,03$ dan $Y=37,5$ sedangkan untuk nilai postesnya setelah perlakuan $\mathrm{X}=80,80$ dan $\mathrm{Y}=$ 65,4 .

\section{SARAN}

Bertolak dari kesimpulan di atas maka saran yang dapat disampaikan adalah

a. Penggunaan alat peraga dari bahan bekas tentang sistem peredaran darah pada manusia diharapkan dapat dipakai oleh guru untuk mengajarkan materi Sistem peredaran darah pada manusia khususnya, untuk meningkatkan hasil belajar biologi.

b. Bagi guru maupun mahasiswa dapat mencoba membuat alat peraga dari bahan bekas untuk materi pelajaran yang lainnya. 


\section{UCAPAN TERIMAKASIH}

Diucapkan terima kasih kepada semua pihak yang telah membantu kami dalam proses penelitian ini, antara lain pihak sekolah SMA Negeri 7 Kota Kupang dan rekanrekan dalam program studi Biologi yang telah membantu dalam proses penelitian sampai selesai. Tuhan memberkati semua pihak yang telah memabntu kami sampai selesai penelitian ini.

\section{DAFTAR PUSTAKA}

Abdullah, Oviana wati dan Khatimah Husnil. Penggunaan alat peraga dari bahan bekas dalam menjelaskan sistem respirasi pada manusia di Man sawang Kabupaten aceh selatan, jurnal pendidikan biologi, vol.3 No.2 tahun 2011

Agustama Yudha dan Muksar makbul. (2013). Identifikasi gaya belajar matematika siswa kelas VII di SMA Neger 14 Malang. Universitas Negeri Malang.

Arikunto, suharsimi. (2006). Prosedur Penelitian Suatu Pendekatan Praktik. PT Rineka Cipta: Jakarta.

Arsyad, A. (2002). Media Pembelajaran, Edisi I. PT Raja Grafindo Persada: Jakarta.

Direktorat jenderal pendidikan menengah kementrian pendidikan dan kebudayaan (2011). Pedoman Pembuatan Alat Peraga Biologi Sederhana untuk SMA.

Djamarah, Zain. (2010).Strategi Belajar Mengajar. PT Rineka Cipta: Jakarta.

FathurrohamanPupuh. (2007). Strategi Belajar Mengajar. Bandung. Refika Aditama.

Hamalik Oemar. (2001). Perencanaan pengajaran berdasakan pendekatan sistem. Bumi Aksara: Jakarta.

Hanafiah Nanang, dkk.(2009), Konsep Strategi Pembelajaran, Bandung. PT Refika Aditama.

Komalasari Kokom. (2010). Pembelajaran Kontekstual. PT Refika Aditama: Bandung.

Sadiman, A, S. Dkk, (1996)Media Pendidikan Pengertian Pengembangan dan Pemanfaatannya, edisi 1. CV . Raja Wali : Jakarta.

Sudjana, N. (2013). Penilaian Hasil Proses Belajar Menegajar. Bandung:PT Remaja Rosdakarya.

Winata Putra, Udin. S. (2005). Strategi belajar mengajar. Jakarta Universitas Terbuka. 